extra-African trade. Membership is made up of three categories of shareholders: Class 'A' Shareholders consisting of African governments, African central banks and sub-regional and regional financial institutions and economic organizations; Class 'B' Shareholders consisting of African public and private financial institutions; and Class ' $\mathrm{C}$ ' Shareholders consisting of international financial institutions, economic organizations and non-African states, banks, financial institutions and public and private investors.

Official languages: English, French, Arabic, Portuguese. Headquarters: World Trade Center, 1191 Corniche El-Nil, Cairo 11221, Egypt.

Website: http//www.afreximbank.com

President and Chairman of the Board: Jean-Louis Ekra (Côte d'Ivoire).

\section{African Union (AU)}

History. The Fourth Extraordinary Session of the Assembly of the Heads of State and Government of the Organization of African Unity (OAU) held in Sirté, Libya on 9 Sept. 1999 decided to establish an African Union. At Lomé, Togo on 11 July 2000 the OAU Assembly of the Heads of State and Government adopted the Constitutive Act of the African Union, which was later ratified by the required two-thirds of the member states of the Organization of African Unity (OAU); it came into force on 26 May 2001. The Lusaka Summit, in July 2001, gave a mandate to translate the transformation of the Organization of African Unity into the African Union, and on 9 July 2002 the Durban Summit, in South Africa, formally launched the African Union.

Aims. The African Union aims to promote unity, solidarity, cohesion and co-operation among the peoples of Africa and African states, and at the same time to co-ordinate efforts by African people to realize their goals of achieving economic, political and social integration.

Activities. The African Union became fully operational in July 2002 , and is working towards establishing 17 organs among which are a Pan-African parliament and a Peace and Security Council (both of which have now been inaugurated), the Economic, Social and Cultural Council (ECOSOC), a Central Bank and a Court of Justice.

Official languages: Arabic, English, French, Ki-Swahili, Portuguese and Spanish.

Headquarters: POB 3243, Addis Ababa, Ethiopia.

Website: http://www.africa-union.org

Chairman: Denis Sassou-Nguesso (Republic of the Congo).

\section{Bank of Central African States (BEAC)}

The Bank of Central African States (Banque des Etats de l'Afrique Centrale) was established in 1973 when a new Convention of Monetary Co-operation with France was signed. The five original members, Cameroon, Central African Republic, Chad, Republic of the Congo and Gabon, were joined by Equatorial Guinea in 1985. Under its Convention and statutes, the BEAC is declared a 'Multi-national African institution in the management and control of which France participates in return for the guarantee she provides for its currency'.
Official language: French.

Headquarters: Avenue Monseigneur Vogt, Yaoundé,

Cameroon.

Website: http://www.beac.int (French only)

Governor: Jean-Félix Mamalepot.

Publications. Etudes et Statistiques (monthly bulletins); Annual Report; Directory of Banks and Financial Establishments of BEAC Monetary Area (annual); Bulletin du Marché Monétaire (monthly bulletins); Annual Report of the Banking Commission.

\section{Central Bank of West African States (BCEAO)}

Established in 1962, the Central Bank of West African States (Banque Centrale des Etats de l'Afrique de l'Ouest) is the common central bank of the eight member states which form the West African Monetary Union (WAMU). It has the sole right of currency issue throughout the Union territory and is responsible for the pooling of the Union's foreign exchange reserve; the management of the monetary policy of the member states; the keeping of the accounts of the member states treasury; and the definition of the banking law applicable to banks and financial establishments.

Members. Benin, Burkina Faso, Côte d'Ivoire, Guinea-Bissau, Mali, Niger, Senegal, Togo.

Official language: French.

Headquarters: Avenue Abdoulaye Fadiga, Dakar, Senegal.

Website: http://www.bceao.int

Governor (acting): Justin Baro Damo (Burkina Faso).

Publications. Rapport annuel (annual); Annuaire des Banques (annual); Bilan des Banques U.M.O.A. (annual); Notes d'information et statistiques (monthly bulletin).

\section{Common Market for Eastern and Southern Africa (COMESA)}

COMESA is an African economic grouping of 20 member states who are committed to the creation of a Common Market for Eastern and Southern Africa. It was established in 1994 as a building block for the African Economic Community and replaced the Preferential Trade Area for Eastern and Southern Africa, which had been in existence since 1981.

Members. Angola, Burundi, Comoros, Democratic Republic of Congo, Djibouti, Egypt, Eritrea, Ethiopia, Kenya, Libya, Madagascar, Malaŵi, Mauritius, Rwanda, Seychelles, Sudan, Swaziland, Uganda, Zambia and Zimbabwe.

Objectives. To facilitate the removal of the structural and institutional weaknesses of member states so that they are able to attain collective and sustainable development.

Activities. COMESA's Free Trade Area (FTA) was launched on 31 Oct. 2000 at a Summit of Heads of States and Government in Lusaka, Zambia. The FTA participating states have zero tariff on goods and services produced in these countries.

In addition to creating the policy environment for freeing trade, COMESA has also created specialized institutions like the Eastern and Southern African Trade and Development Bank 